năng phổi, giảm các biến chứng và thời gian nằm viện. Chăm sóc cuff thường xuyên sẽ giúp giảm nguy cơ nhiễm khuẩn. Beccaria LM và cộng sự (2017) cũng khuyến nghị theo dõi Cuff từ 2 lần/ngày trở lên [3]. Kiều Văn Khương (2019) bệnh viện Quân Y 103 đề cập trong nghiên cứu sự biến đổi áp lực trong bóng cuff ống nội khí quản ở bện nhân thở máy tại khoa Điều trị tích cực. Nghiên cứu cho thấy việc theo dõi áp lực cuff ở người bệnh thở máy là rất cần thiết [4].

Bệnh nhân được đặt nội khí quản có hút trên cuff và theo dõi áp lực hút trên cuff liên tục có tác dụng làm giảm nhiễm khuẩn phổi và hạn chế nguy cơ nhiễm khuẩn phổi. Điều này cho thấy cần gia tăng công tác theo dõi, chăm sóc như: chăm sóc Cuff đảm bảo đủ áp lực hay vỗ rung liệu pháp hô hấp, dẫn lưu tư thế kết hợp sử dụng ống NKQ có hút trên cuff có thể làm tăng kết quả chăm tốt nhất cho công tác chăm sóc của điều dưỡng với người bệnh ngộ độc cấp thở máy. Điều này phù hợp với gói chằm sóc người bệnh thở máy chung mà bệnh viện Bạch Mai đã và đang áp dụng tại các đớn vị Hồi sức. Kết quả của chúng tôi phù hợp với nghiên cứu của một số tác giả trong nước khi nghiên cứu tại một số đơn vị hồi sức [5], [6], [7].

\section{KẾT LUẬN}

Người bệnh ngộ độc cấp có thở máy tại Trung tâm Chống độc Bệnh viện Bạch Mai có kểt quả chăm sóc tốt là $85,2 \%$, chưa tốt $14,8 \%$.

Chăm sóc điều dưỡng có vai trò quan trọng trong công tác chăm sóc người bệnh thở máy. Người bệnh được vỗ rung, lý liệu pháp hô hấp, chăm sóc cuff tích cực cho kết quả chăm sóc tốt hơn. Chăm sóc vỗ rung liệu pháp hô hấp tích cực có khả năng tăng kết quả chăm sóc tốt cao gấp 4,93 lần $(\mathrm{OR}=4,93, \mathrm{p}<0,05)$ so với việc không thực hiện vỗ rung. Chăm sóc cuff > 3 lần/ngày có khả năng kêt quả chăm sóc ở mức tốt cao gấp 4,35 lần $(O R=4,35, p<0,05)$ so với việc chăm sóc với tần suất $\leq 3$ lần/ngày $(p<0,05)$.

\section{TÀI LIÊU THAM KHẢO}

1. Hà Trân Hưng và Hà Thị Bích Vân (2015), "Nguyên nhân các ngô đôcc cấp có rối loạn ý thức taii Trung tâm chống độc bệnh viện Bạch Mai", Tạp chí Nghiên cứu y học. $97(5)$, tr. 99.

2. Bộ Y tế (2018), Niên giám thống kê $Y$ tế 2018, Bổ Y tế, Hà Nô̂i.

3. Beccaria L. M., et al. (2017), "Tracheal cuff pressure change before and after the performance of nursing care", Rev Bras Enferm. 70(6), 1145-1150.

4. Kiêuu Văn Khương (2018), "Nghiên cứu sư biến đổi áp lực trong bóng cuff ống nội khí quản ở bệnh nhân thở máy tại khoa Điều trị tích cực, bệnh viện Quân Y 103", Tạp chí Y dược lâm sàng 108. 14(4), tr. 49-54.

5. Đào Ngọc Sơn (2016), Thực trạng nhiễm khuẩn bệnh viện trên bệnh nhân thở máy tại khoa Hồi sức cấp cứu bệnh viện Nhiệt Đới trung ương, Khoa Chống Độc bệnh viện Bạch Mai và một số yếu tố liên quan, năm 2016, Khóa luận tốt nghiệp Cử nhân Điều dưỡng, Trướng Đại học Thăng Long.

6. Trân Thị Tuệ Tú (2019), Thực trang chăm sóc người bệnh thở máy và các yếu tố liên quan đến nhiễm khuẩn bệnh viện tại các khoa lâm sàng Bệnh viện Bạch Mai năm 2019, Luận văn Thạc sỹ Điều dướng, Trường Đại học Thăng Long.

7. Vũ Thị Yến (2014), Tỷ lệ viêm phổi thở máy ở bênh nhân thơ máy được điểu trị ở một số khoa tai bệnh viện Bạch Mai, năm 2014 và một số yếu tố liển quan, Khóa luận tốt nghiệp Cử nhân Điều dưỡng, Trường Đại học Thăng Long.

\title{
NGHIÊN CỨU TÁC DỤNG SINH CYTOKIN CỦA KHỐI TẾ BÀO CAR-T
}

\section{TÓM TẮT}

Mục tiêu: Nghiên cứu đánh giá khả năng sinh IL2, TNF-a và IFN-Y của các tế bào CAR-T khi đồng nuôi cấy với các dòng tế bào ung thư $C D 19+$. Phương pháp NC: Khả năng sinh các interleukin khi nuôi cây

\footnotetext{
${ }^{1}$ Học viện quân y

Bềnh viên Quân y 103

Chịu trách nhiệm chính: Cấn Văn Mão

Email: canvanmao2011@gmail.com

Ngày nhân bài: 4.01.2021

Ngày phản biên khoa học: 9.3.2021

Ngày duyệt bài: 16.3.2021
}

\section{Cấn Văn Mão ${ }^{1}$, Đặng Thành Chung ${ }^{1}$, Ngô Thu Hằng ${ }^{1}$ Nguyễn Văn $\mathrm{Ba}^{2}$}

khối tế bào CAR-T với các tế bào ung thư (tế bào K562, Daudi, 1D2, PBMC) được đánh giá ở hai thời điểm sau 24 và 48 giờ. IL-2, TNF-a và IFN-y được định lượng bằng các bộ sinh phẩm IL-2 Human ELISA Kit, TNF alpha Human ELISA Kit, IFN gamma Human ELISA Kit (Thermo Fisher Scientific). Kết quả: tại cả hai thời điểm 24 giờ và 48 giờ nông độ các cytokine IFN-y, IL-12, TNF-a trong dịch nuôi cấy của tế bào CAR-T khi nuôi cấy với các tế bào ung thư có CD19+ đều cao hơn có ý nghĩa thống kê $(p<0,05)$ so với nồng độ IFN- $y$, IL-12, TNF-a trong dịch nuôi cấy của tế bào trên với tế bào PBMC (nhóm chứng). Ngoài ra, nồng độ các cytokine trên trong dịch nuôi cây của tế bào CAR-T khi nuôi cấy với các tế bào ung thư có 
CD19+ đều cao hơn so với khi nuôi cây với tế bào CD19-. Kết luâan: sản phẩm CAR-T của đề tài chúng tôi có khả năng sinh IFN- $y, I L-12, T N F-a$ và tăng manh hơn khi nuôii đồng thời với các tế bào có CD19+.

Tư khóa: Tế bào CAR-T, IL-2, IFN-Y, TNF-a, CD19 dương tính.

\section{SUMMARY \\ INVESTIGATE THE ABILITY TO PRODUCE CYTOKINE OF CAR-T CELL}

Objectives: The study on IL-2, TNF-a and IFN secretion of CAR-T cell when co-incubation CD19 + cancer cell lines. Method: Interleukin generation of CAR-T cell when co-culture with other cells (K562, Daudi, 1D2, PBMC cells) was evaluated at 24 and 48 hours after culture. IL-2, TNF-a and IFN were quantified using the probiotics IL-2, TNF alpha, IFN gamma Human ELISA Kit (Thermo Fisher Scientific). Results: At both 24 and 48 hours, the higher concentrations of cytokines IFN- $y$, IL-12, and TNF-a in the CAR-T cell cultures when cultured with cancer cells with CD19 + statistical significance $(p<0.05)$ compared with the concentration of IFN- $y$, IL-12, TNF$a$ in the culture of above cells and PBMC cells (control group). In addition, the concentrations of these cytokines in CAR-T cell cultures were both higher when cultured with CD19 + cancer cells than when cultured with CD19- cells. Conclusion: Our CAR-T product has the ability to generate IFN- $\gamma$, IL-12, TNF$\mathrm{a}$ and increase generation when co-cultured with CD19 positive cells.

Keywords: CAR-T cell, IL-2, IL2, IFN- $\mathrm{Y}$, TNF- $a$, CD19 positive.

\section{I. ĐẶT VẤN ĐỀ}

Điều trị bệnh bạch cầu lymphoblastic cấp tính (ALL) là nhằm tiêu diệt các tế bào bach câu ác tính và phục hồi tuỷ xương trở lại bình thường. Liệu pháp điều trị chủ yễu hiện được sử dụng cho ALL là hóa trị liệu. Hạn chế của các liệu pháp này là tỷ lệ thuyên giảm toàn phần theo đường hướng điều trị này cũng không cao, chỉ đạt tối đa $20 \%$ ở người trưởng thành [1] và chỉ hướng đến thuyên giảm toàn phần để có thể được điều trị tiếp bằng liệu pháp ghép tế bào gốc đồng loài.

Hiện nay, các nhà khoa học đang nghiên cứu các hướng điều trị mới, điển hình liệu pháp sử dụng tế bào $T$ mang thụ thể nhân tạo CAR (Chimeric antigen receptors). Nguyên tắc của liệu pháp CAR-T trong điều trị ung thư là nhằm tạo ra các tế bào $T$ mang các thụ thể nhân tạo có khả năng nhận biết các kháng nguyên đặc hiệu trên bề mặt tế bào ung thư từ đó kích hoạt khả năng phân giải tế bào ung thư của tế bào $T$. Năm 2017, cơ quan thực phẩm và dược phẩm hoa kỳ (FDA) đã cấp phép cho 2 dạng điều trị sử dung CAR-T là Kymriah của hãng Novartis cho đî̀u trị bệnh bạch cầu lympho cấp ở trẻ em và Yescarta của hãng Kite Pharma cho các bệnh lymphoma không phải Hodgkin ở người lớn [2]. Tuy nhiên, ở Việt Nam chưa có nghiên cứu nào ứng dung liệu pháp tế bào CAR-T để điều trị ung thư nói chung và $A L L$ nói riêng. Do đó, chúng tôi tiến hành nghiên cứu ứng dụng liệu pháp tế bào CAR-T trong điều trị bạch câu nguyên bào lympho cấp

Để có cơ sở khoa học đánh giá hiệu quả điều trị bệnh bạch cầu lymphoblastic cấp tính của tế bào CAR-T, tạo tiền đề cho việc thử nghiệm trên động vật thực nghiệm và trên lâm sàng, chúng tôi tiến hành thí nghiệm này với mục đích: Nghiên cứu đánh giá khả năng sinh IL-2, TNF-a và IFN-Y của các tế bào CAR-T khi đồng nuôi cây với các dòng tế bào ung thư CD19+.

\section{II. ĐỐI TƯợNG VÀ PHƯƠNG PHÁP NGHIÊN CỨU 2.1. Đối tượng nghiên cứu}

- Tế bào K562 (ATCC CCL-243) - chronic myelogenous leukemia (CML)

- Tế bào Daudi (ATCC CCL-213) - Burkitt's lymphoma.

- Tế bào CAR-T (sản phẩm của đề tài $\mathrm{KC}$ 10.39/16-20)

- Tế bào trình diện kháng nguyên nhân tạo biểu hiện $\mathrm{CD} 19(+)$ 1D2

- Tể bào đơn nhân máu ngoại vi (PBMC)

\subsection{Phương pháp nghiên cứu}

2.2.1. Phương tiện và hóa chất nghiên cứu

- Môi trường nuô̂i cấy tế bào ung thư RPMI RPMI-1640, huyết thanh bào thai bò (FBS = fetal bovin serum) $10 \%$; dung dich penicillin và streptomycin 1\%; trypsin-EDTA (Invitrogen $\mathrm{GmbH}$, Karlsruhe, Cộng hòa Liên bang Đức).

- Bộ kít ELISA định lượng IL2, IFN- $y$, TNF-a được cung cấp bởi Thermo Fisher Scientific.

- Các vật tư tiêu hao cần thiết phục vụ cho nuôi cấy tế bào: Chai nuôi cấy tế bào, pipet, chai đựng môi trường, lọc vi khuẩn $0,45 \mu \mathrm{m}$ (ATCC, Hoa Kỳ).

- Hệ thống phòng thí nghiệm phục vụ nuôi cấy tế bào: Phòng sạch, tủ ấm $\mathrm{CO} 2$, kính hiển vi soi ngược, máy ly tâm, tủ mát $4^{\circ} \mathrm{C}$, tủ âm $-20^{\circ} \mathrm{C}$, $-80^{\circ} \mathrm{C}$, bình chứa Nitơ lỏng

\subsection{Phương pháp nghiên cứu}

Nghiên cứu được thiết kế là nghiên cứu thực nghiệm, mô tả cắt ngang có đối chứng.

2.2.1. Kỹ thuật nuôi cấy tế bào

a, Tế bào K562, Daudi. Tế bào K562 $(1 \mathrm{~mL})$ bảo quản ở $-80^{\circ} \mathrm{C}$ trong FBS (10\% DMSO) được làm ấm nhanh ở $37^{\circ} \mathrm{C}$ trong khoảng 1 phút. Sau đó, $20 \mathrm{~mL}$ môi trường RPMI 1640 (10\% FBS) được bổ sung từ từ vào ống tế bào trước khi ly tâm ở $200 \mathrm{~g}$ trong 10 phút. 
Sau khi loại bỏ toàn bô dich nổi, cặn tế bào được hòa tan bằng môi trường nuôi cấy RPMI $1640\left(10 \% \mathrm{FBS}, 37^{\circ} \mathrm{C}\right)$ nhằm đưa mật độ tế bào về $10^{5}$ tế bào/mL.

Tế bào được nuôi trong chai T25 ở $37^{\circ} \mathrm{C}$, $5 \%$ CO2, độ ẩm > 90\%, không lắc đến khi mật độ đạt $10^{6}$ tế bào/mL thì tiến hành cây chuyển về $5 \times 10^{5}$ tế bào $/ \mathrm{mL}$.

b, Tách PBMC: Máu tươi (đã xử lý chống đông) được pha loãng với PBS $1 X(\mathrm{pH} 7,2)$.

Sau đó, $10 \mathrm{ml}$ hỗn hợp trên được đưa vào ống falcon $15 \mathrm{ml}$ chứa sẵn $3 \mathrm{ml}$ Ficoll-Paque PREMIUM $(p=1,077 \mathrm{~g} / \mathrm{mL})$ (tránh trộn lẫn Ficoll với hỗn hợp máu - PBS).

Các ống falcon được ly tâm lạnh tại 400 vòng trong 35 phút (không sử dụng chế độ phanh). Sau khi ly tâm, lớp PBMC (nằm giữa plasma và Ficoll) được hút ra và hòa vào $10 \mathrm{ml} P B S 1 X$ $(0,5 \%$ BSAं; $p H 7,2)$. Hỗn hợp trên được ly tâm lanh ở 160 vòng trong 10 phút. Sau khi lặp lại bước trên, dịch nổi được loại bỏ hoàn toàn và sinh khối tế bào được hòa tan bằng $4 \mathrm{ml}$ môi trường nuôi cây CTS Optimizer complete. $200 \mu \mathrm{l}$ PBMC được sử dụng cho đếm tế bào và phân tích bằng flow cytometry.

C, Nuôi PBMC: Tế bào PBMC (trước và sau chuyển nạp) được nuôi trong OpTmizer:tm: CTS:tm: T-Cell Expansion medium hoăc RPMI1640 (10\% FBS) và được duy trì ở mật độ $10^{6}$ tế bào/mL. Tế bào trình diện kháng nguyên nhân tạo (aAPC) được bổ sung vào môi trường nuôi cấy ở tỉ lệ 1 aAPC : 2 tế bào CAR dương tính mỗi 7 ngày. IL-2 được bổ sung ở nồng độ $50 \mathrm{U} / \mathrm{mL}$ mỗi 2 ngày.

\subsubsection{Einh lương IL-2, TNF- $\alpha$ và IFN- $\gamma$ bằng} kỹ thuạt ELISA

Khả năng sinh IL-2, TNF- $\alpha$ và IFN- $\gamma$ của các tế bào CAR-T khi đồng nuôi cấy với tế bào CD19+ sẽ được tiến hành trên hai dòng tế bào ung thư $\mathrm{CD} 19+$ là Daudi và tế bào trình diện kháng nguyên 1D2 (K562 có trình diên CD19+) tại 2 thời điểm 24 giờ và 48 giờ. Tế bào CD19(-) được sử dụng đối chứng là K562 và nhóm chứng sử dụng tế bào PBMC.

- Nhóm Daudi-CAR-T $(n=3): 10^{6} / \mathrm{mL}$ tế bào CAR-T được nuôi đồng thời cùng $106 / \mathrm{mL}$ tế bào Daudi (có biểu hiện CD19+)

- Nhóm 1D2-CAR-T $(\mathrm{n}=3): 10^{6} / \mathrm{mL}$ tế bào CAR-T được nuôi đồng thời cùng $10^{6} / \mathrm{mL}$ tế bào K562 có trình diện kháng nguyên (có biểu hiện CD19+).

- Nhóm K562-CAR-T $(\mathrm{n}=3): 106 / \mathrm{mL}$ tế bào CAR-T được nuôi đồng thời cùng $10^{6} / \mathrm{mL}$ tế bào K562 (không biểu hiện CD19)
- Nhóm chứng Daudi-PBMC $(\mathrm{n}=3): 10^{6} / \mathrm{mL}$ tế bào PBMC được nuôi đồng thời cùng $10^{6} / \mathrm{mL}$ tế bào Daudi (có biểu hiện CD19+)

Nhóm chứng 1D2-PBMC $(\mathrm{n}=3): 10^{6} / \mathrm{mL}$ tế bào PBMC được nuôi đồng thời cùng $10^{6} / \mathrm{mL}$ tế bào K562 có trình diện kháng nguyên (có biểu hiện CD19+).

- Nhóm chứng K562-PBMC $(\mathrm{n}=3): 10^{6} / \mathrm{mL}$ tế bào PBMC được nuôi đồng thời cùng $10^{6} / \mathrm{mL}$ tế bào K562 (không biểu hiện CD19) IL-2, TNF-a và IFN- $\gamma$ được định lượng bằng các bộ sinh phẩm IL-2 Human ELISA Kit, TNF alpha Human ELISA Kit, IFN gamma Human ELISA Kit (Thermo Fisher Scientific).

\section{Quy trinh thử nghiệm:}

Bước 1. Chuẩn bị hóa chất: Dung dịch rửa 1X: Dung dịch đệm rửa được pha loãng từ dung dịch gốc $25 X$ theo tỷ lệ $1 / 25$ với nước cất bằng cách pha $16 \mathrm{~mL}$ dung dịch rửa $25 \mathrm{X}$ với $384 \mathrm{ml}$ nước cất ta được $400 \mathrm{~mL}$ dung dịch rửa $1 X$. Chuẩn bị các nồng độ chuẩn (standards). Chuẩn bi dung dịch HRP trước khi sử dụng: Pha loãng 100 lần bằng cách cho $120 \mu \mathrm{l}$ dung dịch HRP streptavidin với $12 \mathrm{~mL}$ Streptavidin-HRP Diluent.

Bước 2. Đưa các mẫu thử vào giếng của phiến 96 giếng theo sơ đồ mẫu. Đưa $100 \mu \mathrm{L}$ dung dịch các nồng độ chuẩn vào các giếng chuẩn. Cho $100 \mu \mathrm{L}$ dung dịch mẫu vào giếng. Trộn đều nhẹ nhàng. Trong khay đĩa microelisa, đế lại hai giếng trống làm mấu chứng trắng (blank control). Đóng tấm màng che khay đĩa và ủ ở nhiệt độ phòng trong 2 giờ.

Bước 3. Rửa: bóc tấm màng che khay đĩa, hút dịch trong các giếng ra và bơm $400 \mu \mathrm{L}$ dung dịch rửa $1 X$ vào mỗi giêng. Lặp lại qui trình rửa 4 lần.

Bước 4. Cho thêm 100ul dung dịch Biotinylated antibody đã chuẩn bị vào mối giếng. Đậy nắp và ủ 1 giờ ở nhiệt độ phòng.

Bước 5. Rửa: bóc tấm màng che khay đĩa, hút dich trong các giếng ra và bơm $400 \mu \mathrm{L}$ dung dịch rửa $1 X$ vào mỗi giếng. Lặp lại qui trình rửa 4 lần.

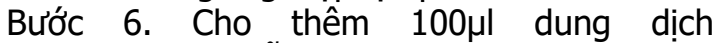
Streptavidin vào mỗi giếng. Đậy nắp và ủ 30 phút ở nhiệt độ phòng và lắc nhẹ $300 \mathrm{rpm} / \mathrm{p}$. hút.

Bước 7. Rửa: bóc tấm màng che khay đĩa, hút dịch trong các giếng ra và bơm $400 \mu \mathrm{L}$ dung dịch rửa $1 \mathrm{X}$ vào mỗi giếng. Lặp lại qui trình rửa 4 lần.

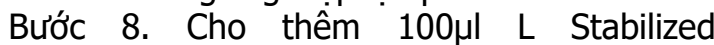
Chromogen (TMB) vào mỗi giếng. Đậy nắp và ủ 30 phút ở nhiệt độ phòng, trong phòng tối.

Bước 9. Cho thêm 100ul dung dịch dừng phản ứng (stop solution) vào mỗi giếng. Đọc kết quả ngay ở bước sóng 450nm 
2.3. Xử lý thống kê: So sánh trung bình của 2 nhóm độc lập bằng T-test, so sánh trung bình của 3 nhóm bằng phân tích phương sai ANOVA. Số liệu được xử lý bằng phần mềm SPSS 20.0 và GraphPad Prism 6. Sự khác biệt có ý nghĩa thống kê khi $p<0,05$.

III. KẾT QUẢ NGHIÊN CứU

3.1. Kết quả tăng sinh IL-2 của các tế bào CAR-T khi đồng nuôi cây với các dòng tế bào ung thư CD19+

Bảng 3.1. Nồng độ IL-2 trong dịch nuôi cây của tế bào CAR-T và PBMC với các dòng tế bào ung thư máu

\begin{tabular}{|c|c|c|}
\hline \multirow{2}{*}{ Nhóm } & \multicolumn{2}{|c|}{ Nồng độ IL-2 (pg/ mL) } \\
\cline { 2 - 3 } & $\mathbf{2 4}$ giờ & $\mathbf{4 8 ~ g i o ̛ ́ ~}$ \\
\hline 1D2-PBMC (1) & $1,916 \pm 0,888$ & $2,857 \pm$ \\
& & 0,294 \\
\hline Daudi-PBMC & $2,278 \pm 0,391$ & $2,439 \pm$ \\
$(2)$ & 0,289 \\
\hline K562-PBMC & $1,501 \pm 0,057$ & $2,760 \pm$ \\
$(3)$ & 0,242 \\
\hline 1D2-CART (4) & $18,556 \pm$ & $31,378 \pm$ \\
& 1,197 & 2,137 \\
\hline Daudi-CART & $17,744 \pm$ & $24,045 \pm$ \\
$(5)$ & 2,057 & 3,985 \\
\hline K562-CART & $10,748 \pm$ & $7,207 \pm$ \\
$(6)$ & 1,400 & 1,806 \\
\hline & $\mathrm{p}_{41}<0,05 ;$ & $\mathrm{p}_{41}<0,05 ;$ \\
& $\mathrm{p}_{52}<0,05 ;$ & $\mathrm{p}_{52}<0,05 ;$ \\
$\mathrm{p}_{63} *$ & $\mathrm{p}_{63}<0,05$ & $\mathrm{p}_{63}<0,05$ \\
& $\mathrm{p}_{46}<0,05 ;$ & $\mathrm{p}_{46}<0,05 ;$ \\
& $\mathrm{p}_{56}<0,05$. & $\mathrm{p}_{56}<0,05$. \\
\hline
\end{tabular}

*: Mann-whitney test

Kết quả ở các bảng 3.1 cho thấy: tại cả hai thời điểm 24 giờ và 48 giờ nồng độ IL-2trong dịch nuôi cấy của tễ bào CAR-T khi nuôi cấy với các tế bào ung thư có $C D 19+(1 D 2$ và Daudi) và tế bào CD19- (K562) đều cao hơn có ý nghĩa thống kê $(p<0,05)$ so với nồng đô IL-2trong dich nuôi cấy của tế bào PBMC (nhóm chứng) khi nuôi cấy với các tế bào trên.

Mặt khác, nồng độ IL-2 trong dịch nuôi cấy của tế bào CAR-T khi nuôi cấy với các tế bào ung thư có CD19+ (1D2 và Daudi) đều cao hơn có ý nghĩa thống kê $(p<0,05)$ so với nồng độ IL2trong dịch nuôi cấy của tế bào CAR-T khi nuôi cấy với tế bào CD19- (K562).

Kết quả này cho thấy CAR-T có khả năng kích thích tăng sinh IL-2 và tăng sinh mạnh hơn khi nuôi đồng thời với các tế bào có $C D 19+$.

3.2. Kết quả tăng sinh IFN-Y của các tế bào CAR-T khi đồng nuôi cây với các dòng tế bào ung thư CD19+
Bảng 3.2. Nồng độ IFN-y trong dịch nuôi cây của tế bào CAR-T và PBMC với các dòng tế bào ung thư máu

\begin{tabular}{|c|c|c|}
\hline \multirow{2}{*}{ Nhóm } & \multicolumn{2}{|c|}{ Nồng độ IFN-Y ( $\mathbf{~ g / ~} \mathbf{~ m L})$} \\
\cline { 2 - 3 } & $\mathbf{2 4}$ giờ & $\mathbf{4 8}$ giơ \\
\hline \multirow{2}{*}{ 1D2-PBMC (1) } & $39,272 \pm$ & $10,964 \pm$ \\
& 4,471 & 5,717 \\
\hline \multirow{2}{*}{ Daudi-PBMC (2) } & $52,090 \pm$ & $30,367 \pm$ \\
& 9,899 & 11,745 \\
\hline \multirow{2}{*}{ K562-PBMC (3) } & $29,697 \pm$ & $5,344 \pm$ \\
& 3,711 & 4,003 \\
\hline \multirow{2}{*}{ 1D2-CART (4) } & $104,183 \pm$ & $47,103 \pm$ \\
& 9,071 & 18,752 \\
\hline \multirow{2}{*}{ Daudi-CART (5) } & $157,574 \pm$ & $211,386 \pm$ \\
& 4,841 & 104,113 \\
\hline \multirow{2}{*}{ K562-CART (6) } & $49,563 \pm$ & $14,490 \pm$ \\
& 9,701 & 7,068 \\
\hline & $\mathrm{p}_{41}<0,05 ;$ & $\mathrm{p}_{41}<0,05 ;$ \\
& $\mathrm{p}_{52}<0,05 ;$ & $\mathrm{p}_{52}<0,05 ;$ \\
& $\mathrm{p}_{63}>0,05$ & $\mathrm{p}_{63}>0,05$ \\
p* & $\mathrm{p}_{46}<0,05 ;$ & $\mathrm{p}_{46}<0,05 ;$ \\
& $\mathrm{p}_{56}<0,05$. & $\mathrm{p}_{56}<0,05$. \\
\hline
\end{tabular}

*: Mann-whitney test

Kết quả ở các bảng 3.2 cho thấy: tại cả hai thời điểm 24 giờ và 48 giờ nồng độ IFN-y trong dịch nuôi cấy của tế bào CAR-T khi nuôi cấy với các tế bào ung thư có CD19+ (1D2 và Daudi) đều cao hơn có ý nghĩa thống kê $(p<0,05)$ so với nồng độ IFN-y trong dịch nuôi cấy của tế bào PBMC (nhóm chứng) khi nuôi cấy với các tế bào trên.

Mặt khác, nồng độ IFN-y trong dịch nuôi cấy của tế bào CAR-T khi nuôi cấy với các tế bào ung thư có CD19+ (1D2 và Daudi) đều cao hơn có ý nghĩa thống kê $(p<0,05)$ so với nồng độ IFN-Y trong dịch nuôi cấy của tế bào CAR-T khi nuôi cây với tế bào CD19- (K562).

Kết quả này cho thấy CAR-T có khả năng kích thích tăng sinh IFN-y và tăng sinh mạnh hơn khi nuôi đồng thời với các tế bào có CD19+.

3.3. Kết quả tăng sinh TNF-a của các tế bào CAR-T khi đồng nuôi cấy với các dòng tế bào ung thư CD19+

Bảng 3.3. Nồng độ TNF-a trong dịch nuôi cấy của tế bào CAR-T và PBMC với các dòng tế bào ung thư máu

\begin{tabular}{|c|c|c|}
\hline \multirow{2}{*}{ Nhóm } & Nồng độ TNF-a (pg/ mL) \\
\cline { 2 - 3 } & $\mathbf{2 4 ~ g i o ̛ ̀ ~}$ & $\mathbf{4 8 ~ g i o ̛ ̀ ~}$ \\
\hline \multirow{2}{*}{ D2-PBMC (1) } & $28,033 \pm$ & $8,658 \pm$ \\
& 12,512 & 14,996 \\
\hline Daudi-PBMC & $8,658 \pm$ & $26,960 \pm$ \\
$(2)$ & 14,996 & 27,467 \\
\hline K562-PBMC & $8,658 \pm$ & $48,274 \pm$ \\
(3) & 14,996 & 22,529 \\
\hline 1D2-CART (4) & $11,756 \pm$ & $32,837 \pm$ \\
\hline
\end{tabular}




\begin{tabular}{|c|c|c|}
\hline & 20,361 & 27,986 \\
\hline $\begin{array}{c}\text { Daudi-CART } \\
\text { (5) }\end{array}$ & $57,930 \pm$ & $60,522 \pm$ \\
28,549 & 33,038 \\
\hline \multirow{2}{*}{ K562-CART (6) } & $11,119 \pm$ & $13,816 \pm$ \\
& 9,630 & 23,929 \\
\hline & $\mathrm{p}_{41}>0,05 ;$ & $\mathrm{p}_{41}>0,05 ;$ \\
& $\mathrm{p}_{52}<0,05 ;$ & $\mathrm{p}_{52}>0,05 ;$ \\
& $\mathrm{p}_{63}>0,05$ & $\mathrm{p}_{63}>0,05$ \\
& $\mathrm{p}_{46}>0,05 ;$ & $\mathrm{p}_{46}>0,05 ;$ \\
& $\mathrm{p}_{56<0,05 .}$ & $\mathrm{p}_{56<0,05}$ \\
\hline
\end{tabular}

*: Mann-whitney test

Kết quả ở các bảng 3.3 cho thấy: tại thời điểm 24 và 48 giờ, nồng độ TNF-a trong dịch nuôi cây của tế bào CAR-T khi nuôi cấy với tế bào Daudi, K562 cao hơn so với nồng độ TNF-a trong dịch nuôi cấy của tế bào PBMC (nhóm chứng) khi nuôi cấy với các tế bào trên; sự khác biệt có ý nghĩa thống kê $(p<0,05)$ ở nhóm nuôi đồng thời cùng Daudi tại thời điểm 24 giờ.

Mặt khác, tại cả 2 thời điểm 24 và 48 giờ, nồng độ TNF-a trong dịch nuôi cấy của tế bào CAR-T khi nuôi cấy với các tế bào ung thư có CD19+ (1D2 và Daudi) đều cao hơn so với nồng độ TNF-a trong dịch nuôi cấy của tế bào CAR-T khi nuôi cấy với tế bào CD19- (K562), sự khác biệt có ý nghĩa thống kê $(p<0,05)$ ở nhóm Daudi với K562.

Kết quả này cho thãy CAR-T có khả năng kích thích tăng sinh TNF-: -và tăng sinh mạnh hơn khi nuôi đồng thời với các tế bào có CD19+.

\section{BÀN LUÂN}

Cơ quan Quản lý Thực phẩm và Dược phẩm Hoa Kỳ (FDA) đã phê duyệt ba công nghệ thụ thể kháng nguyên khảm (CAR) để điều trị lymphoma ác tính. Các tế bào lympho $\mathrm{T}$ sở hữu thụ thể tế bào $T$ đăc hiệu, nhạy cảm và liên tục tìm kiếm các tín hiệu ung thư, qua đó kích thích đáp ứng miễn dịch liên tiếp khi xác định được các kháng nguyên ung thư. Do vậy tế bào $T$ có khả năng giết tế bào ung thư tiềm tàng một cách chính xác. Tuy nhiên, tế bào $T$ thông thường chỉ có thể tấn công yếu ớt hoặc không thể chống lại tế bào đã bị biến đổi do: (1) Tính sinh kháng nguyên nghèo nàn, (2) Không biểu hiện kiểu hình rõ ràng, (3) Khả năng tương tác và ức chế đáp ứng miến dịch cao của các tế bào biến đổi. Do vậy thụ thể kháng nguyên khảm (Chimeric Antigen Receptors, CARs) đã được phát triển để kích thích và hoạt hoá đáp ứng của tế bào $T$ chống lại tế bào ung thư [3].

Liệu pháp tế bào CAR-T thế hể đầu tiên chủ yếu nhắm vào $C D-19$, một loại protein được tìm thấy trên bề mặt của hầu hết các tế bào $B$ bình thường và ác tính trong các bệnh ung thư do tế bào $B$ như lymphoma. Tế bào $T$ biểu hiện CARs (CAR-T cells) có tiềm năng đáng kinh ngạc chống lại các bệnh ung thư máu. Hàng loạt các thử nghiệm lâm sàng sử dụng CD19-CAR-T cho thấy tỳ lệ đáp ứng từ 50-90\% đồi với ung thư tế bào lympho $\mathrm{B}$ không kiểm soát được bằng các liệu pháp thông thường [4], [5]. Cơ chế tác động chính của CAR-T là do CARs chuyển các tín hiệu nhận dạng kháng nguyên thành một thác truyền tín hiệu tác động lên các chức năng đáp ứng của tễ bào $T$ như: tiết các nhân tố gây độc, các cytokine tiền viêm.

Kết quả nghiên cứu của chúng tôi cho thấy: tại cả hai thời điểm 24 giờ và 48 giờ nồng độ các cytokine IFN- $y$, IL-12, TNF-a trong dịch nuôi cấy của tế bào CAR-T khi nuôi cấy với các tế bào ung thư có CD19+ đều cao hơn có ý nghĩa thống kê $(p<0,05)$ so với nồng độ IFN- - , IL-12, TNF-a trong dịch nuôi cấy của tế bào trên với tế bào PBMC (nhóm chứng).

Ngoài ra, nồng độ các cytokine trên trong dịch nuôi cấy của tế bào CAR-T khi nuôi cấy với các tế bào ung thư có CD19+ đều cao hơn so với khi nuôi cấy với tế bào CD19-. Kết quả này cho thãy sản phẩm CAR-T của đề tài chúng tôi có khả năng kích thích tăng sinh IFN- $\gamma$, IL-12, TNFa và tăng sinh manh hơn khi nuôi đồng thời với các tế bào có $C D 19+$. Điều này hoàn toàn phù hợp với cơ chế tác dụng của liệu pháp CAR-T.

\section{KẾT LUÂN}

Nghiên cứu của chúng tôi cho thấy tế bào CAR-T có khả năng tăng sinh IL-2, TNF-. và IFN - khi đồng nuôi cấy với các dòng tế bào ung thư CD19+.

\section{TÀI LIÊU THAM KHẢO}

1. Terwilliger, T. and $M$. Abdul-Hay, Acute lymphoblastic leukemia: a comprehensive review and 2017 update. Blood Cancer J, 2017. 7(6): p. e577.

2. Novartis, Prescribing Information $\left(K_{y m r i a h}{ }^{\mathrm{TM}}\right)$. 2017.

3. D'Aloia, M.M., et al., CAR-T cells: the long and winding road to solid tumors. Cell Death Dis, 2018. 9(3): p. 282.

4. Maude, S.L., et al., Chimeric antigen receptor $T$ cells for sustained remissions in leukemia. N Engl J Med, 2014. 371(16): p. 1507-17.

5. Kochenderfer, J.N., et al., Chemotherapyrefractory diffuse large B-cell lymphoma and indolent B-cell malignancies can be effectively treated with autologous T cells expressing an antiCD19 chimeric antigen receptor. J Clin Oncol, 2015. 33(6): p. 540-9. 